\title{
Catherine Delons, Baudelaire et Caroline Aupick
}

\author{
Ida Merello
}

\section{(2) OpenEdition}

\section{Journals}

\section{Edizione digitale}

URL: http://journals.openedition.org/studifrancesi/3806

DOI: 10.4000/studifrancesi.3806

ISSN: 2421-5856

\section{Editore}

Rosenberg \& Sellier

\section{Edizione cartacea}

Data di pubblicazione: 1 décembre 2012

Paginazione: 595

ISSN: 0039-2944

\section{Notizia bibliografica digitale}

Ida Merello, «Catherine Delons, Baudelaire et Caroline Aupick», Studi Francesi [Online], 168 (LVI | III) |

2012, online dal 30 novembre 2015, consultato il 05 mars 2021. URL: http://journals.openedition.org/ studifrancesi/3806 ; DOI: https://doi.org/10.4000/studifrancesi.3806

Questo documento è stato generato automaticamente il 5 mars 2021.

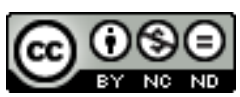

Studi Francesi è distribuita con Licenza Creative Commons Attribuzione - Non commerciale - Non opere derivate 4.0 Internazionale. 


\title{
Catherine Delons, Baudelaire et Caroline Aupick
}

\author{
Ida Merello
}

\section{NOTIZIA}

CATHERINE DELONS, L'Idée si douce d'une mère. Charles Baudelaire et Caroline Aupick, Paris, Les Belles Lettres, 2011, pp. 264.

1 Il rapporto tra Baudelaire e la madre focalizzato sulla figura di Caroline: nata a Londra da due emigrati, Julie Foyot e l'ufficiale realista Charles Dufaÿs, orfana ben presto di entrambi i genitori, accolta a Parigi nella famiglia di un benefattore, sposa dell'amico di lui, François Baudelaire, che intendeva con questo matrimonio assicurarne il benessere economico, e finalmente risposata con Aupick. L'A.ripercorre con attenzione minuziosa tutti i dettagli della sua esistenza, interrogandosi sulla sua personalità: garrula e superficiale, come la descrivono gli amici di Baudelaire, che cercano di allontanarla da lui, dopo l'emiplegia, per evitargli l'evidente irritazione, o brillante donna di società, ringraziata per questa dote da Aupick nella sua lettera testamentaria? Se i rapporti tra il poeta e la madre sono già stati oggetto di abbondante trattazione critica, e affrontati anche dal punto di vista psicanalitico, l'A. riesce tuttavia a trovare nuovi elementi e nuovi argomenti per l'analisi storica del celebre rapporto, con un'esplorazione delle radici della famiglia che non era mai stata affrontata così capillarmente. Emerge in tal modo un ritratto complesso della donna; mentre lo stesso generale Aupick risulta meno monoliticamente insensibile alle ragioni del figliastro di quanto di solito appaia. 